\title{
Antiproliferative and apoptosis effect of hyptolide from Hyptis pectinata (L.) Poit on human breast cancer cells
}

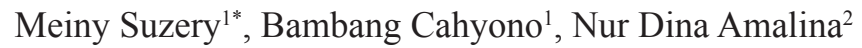 \\ ${ }^{1}$ Chemistry Department, Faculty of Sciences and Mathematics, Diponegoro University, Semarang, Indonesia. \\ ${ }^{2}$ Pharmacy Study Program, Chemistry Department, Faculty of Mathematics and Natural Sciences, Semarang State University, Semarang, Indonesia.
}

\begin{tabular}{l}
\hline ARTICLE INFO \\
\hline Received on: $26 / 09 / 2019$ \\
Accepted on: $24 / 12 / 2019$ \\
Available online: 05/02/2020
\end{tabular}

\section{Key words:}

Hyptis pectinata (L.)

Poit, hyptolide, cytotoxic, apoptosis, antiproliferative, MCF-7 cells.

\begin{abstract}
Hyptolide was isolated from the leaves of Hyptis pectinata (L.) Poit and was studied in order to discover and develop an anticancer drug. Hyptolide was obtained as a crystal of $87^{\circ} \mathrm{C}-88^{\circ} \mathrm{C}$ melting point. Spectroscopic identification results show a wave number at $1,735 \mathrm{~cm}^{-1}$ indicating the presence of $\alpha, \beta$-unsaturated $\delta$-lactone. Gas chromatography-mass spectrometry (GC-MS) analysis provides a single peak in the retention time of $11.701 \mathrm{by} \mathrm{m} / \mathrm{z}$ value at 239, which indicates explicitly hyptolide. The objective of this research was to evaluate the hyptolide's mechanism of cytotoxic on MCF-7 human breast cancer cells in positive estrogen receptor. The assay test to 3-(4,5-dimethylthiazol-2-yl)-2,5dphenyl tetrazolium bromide (MTT) showed that hyptolide exhibited cytotoxic effects on MCF-7 and T47D breast cancer cells with an $\mathrm{IC}_{50}$ value of 76.76 and $181.55 \mu \mathrm{g} / \mathrm{ml}$, respectively. Interestingly, the treatment of hyptolide for 24 , 48, and 72 hours decreased cell viability on MCF-7 with dose- and time-dependent manner compared to untreated cells. Results of acridine orange-ethidium bromide multiple staining assay revealed that hyptolide induced apoptosis in a dosedependent manner. It can be concluded that hyptolide possesses antiproliferative effects through apoptosis induction.
\end{abstract}

\section{INTRODUCTION}

Breast cancer frequently occurs among women, impacting 2.1 million women each year. It also causes the highest number of women with cancer-related death (Sasco, 2003; WHO, 2018). Breast cancer is the most common cancer in Indonesia and is a leading cause of mortality, where 21.5 deaths in every 100,000 persons are caused by breast cancer (Mardela et al., 2017; Sinaga et al., 2018). The most effective treatments for breast cancer are chemotherapy, radiation therapy, and surgery or in special cases, they used in combination (Takimoto and Calvo, 2005). Unfortunately, long-term effects of these cancer treatments have several side effects such as anemia, appetite loss, fatigue, alopecia, toxicity, and drug resistance (Kayl and Meyers, 2006; Tacar et al., 2013). Over the past 30 years, the estrogen receptor (ER) has been the most critical target and implicated to breast cancer

\section{"Corresponding Author}

Meiny Suzery, Chemistry Department, Faculty of Sciences and Mathematics, Diponegoro University, Semarang, Indonesia. E-mail:meiny_suzery@yahoo.com progression (Ariazi and Jordan, 2006; Paruthiyil et al., 2004; Roy and Vadlamudi, 2012). Blocking the action of estrogen has been shown to reduce breast cancer proliferation and incidence in high-risk women by $50 \%-75 \%$ (Lewis-Wambi and Jordan, 2009; Tian et al., 2018). The previous study also found that estrogen administration causes breast cancer while antiestrogen prevents it (Hollingsworth et al., 1998; Jenie et al., 2019). Those findings provide compelling evidence that estrogen and ER have a significant role in the progression of breast cancer. Therefore, based on this reason, the development of new cytotoxic activity in a natural product is significantly crucial for the discovery of safer and more effective chemotherapy agent on ER-positive breast cancer.

One of the herbal plants Hyptis pectinata (L.) Poit popularly known in Brazil as "sambacaita" or "canundiho" (Franzotti et al., 2001) - belongs to one of the family lamiaceae and easily found in another tropical as America, Africa, India, and Indonesia. Hyptis pectinata (L.) Poit has been proven to have several kinds of effects, such as antinociceptive, antiedematogenic, analgesic, anti-inflammatory, and anticancer (Arrigoni-blank et al., 2008; Lisboa et al., 2006; Raymundo et al., 2011). The 
previous study also reported that Hyptis pectinata (L.) poit extract inhibits cancer cell growth on HCT-8, MDA-MB-231, and MCF-7 cells (Barbosa et al., 2012; Santana et al., 2019; Suzery and Cahyono, 2014). The major compound of this plant is hyptolide $(\alpha, \beta$ unsaturated $\delta$ - lactone) with $2 \%$ yield and minor compounds are pectinolide A-G, sambacaitaric acid, and 3-O-methyl-sambacaitaric acid (Falcao et al., 2013; Miranda et al., 1993). Pectinolide A-C exhibit significant antimicrobial and cytotoxic activities on many types of cancer, specifically human breast cancer cells (Miranda et al., 1993). That demonstrates the antitumor potential of this secondary metabolites class. To date, no studies have reported the primary compound of this plant (hyptolide isolated from Hyptis pectinata (L.) Poit), which concerns on antitumor activities and suggests hyptolide as an anticancer agent. In this research, we observed the effect of hyptolide isolated from Hyptis pectinata (L.) Poit on the cell viability, proliferation, and apoptosis on ER-positive breast cancer cells.

\section{MATERIALS AND METHODS}

\section{Plant material}

Hyptis pectinata (L.) Poit was collected in October 2014 in Kanayakan village, Bandung West Java, Indonesia (Latitude -7.0460282; Longitude 107.7915393). For biological studies, the leaves were dried in a renewal air oven and circulated at $40^{\circ} \mathrm{C}$ until it is completely dehydrated. The Biologist at Ecology and Biosystematics Laboratory, Faculty Science and Mathematics, Diponegoro University, Semarang, Indonesia confirmed the identification of the plant (USDA, 2016). A Voucher specimen (MS 100562) was deposited at the Herbarium Biology, Faculty Science and Mathematics, Diponegoro University, Semarang, Indonesia.

\section{Extraction and isolation procedure}

Dried powdered leaves $(0.710 \mathrm{~kg})$ were extracted by the maceration method using methanol at room temperature. After filtration, the solvent was evaporated to result in the crude extracts of the plant under reduce pressure in a rotary vacuum evaporator. The crude extracts were dissolved in water for 24 hours, and the partitioned water-methanol was evaporated until dry. Hyptolide was isolated in $1.7 \%$ yield from extracts of methanol (Achmad et al., 1987; Suzery et al., 2012).

\section{Cell culture}

Michigan Cancer Foundation (MCF-7) and T47D cells were collected from the American Type Culture Collection. MCF-7 and T47D cells were particularly cultured in Dulbecco's Modified Eagle's Medium (Gibco, USA) with 10\% (v/v) fetal bovine serum (Gibco, USA), $12.5 \mu \mathrm{g} / \mathrm{ml}$ Amphotericin B (Gibco), $150 \mu \mathrm{g} / \mathrm{ml}$ Streptomycin, and $150 \mathrm{IU} / \mathrm{ml}$ penicillin (Gibco). Cells were cultivated at $37^{\circ} \mathrm{C}$ with $5 \% \mathrm{CO}_{2}$ in a humidified atmosphere.

\section{Cytotoxic assay}

The cytotoxicity of hyptolide was tested using MTT (3-(4,5-dimethylthiazol-2-yl)-2,5-dphenyl tetrazolium bromide) with slight modifications (Mosmann, 1983). MCF-7 and T47D cells $\left(2 \times 10^{4}\right)$ were seeded in a 96-well microplate and divided into the untreated and treated group. The medium substituted after
24 hours of incubation with a series of hyptolide concentrations. Cells were treated with hyptolide $(1,562-100 \mu \mathrm{g} / \mathrm{ml})$. Untreated cells were regarded as negative controls. After 24-hour-treatment, the medium was removed and substituted with $0.5 \mathrm{mg} / \mathrm{ml}$ of MTT (Biovision) and incubated for approximately four hours at $37^{\circ} \mathrm{C}, 5 \% \mathrm{CO}_{2}$. Cells were lysed using $10 \%$ stopper of sodium dodecyl sulfate containing $0.01 \mathrm{~N} \mathrm{HCl}$ and incubated overnight in the dark condition to dissolve formazan salt. After incubation, the absorbance was measured by Enzyme-linked Immunosorbent Assay reader plate at $\lambda 550 \mathrm{~nm}$. The absorbance was transformed to $\%$ cell viability by comparing the treated group with the untreated at a particular time course. Linear regression between concentration and $\%$ viability of cells giving the equation $y=\mathrm{Bx}$ $+\mathrm{A}$ was used to calculate $\mathrm{IC}_{50}$ value, which was the concentration inhibiting 50\% cell proliferation.

\section{Proliferation assay}

In the experiments of proliferation level measurement, 5 $\times 10^{4} \mathrm{MCF}-7$ cells were seeded in 96-well microplate and treated with hyptolide at several concentrations $(1,562-100 \mu \mathrm{g} / \mathrm{ml})$ for 24 , 48, and 72 hours before MTT.

\section{Apoptosis assay}

MCF-7 cells grown on coverslips determined the apoptosis induction of hyptolide on MCF-7 cells were included in the 24 microplate wells to obtain a density of $5 \times 10^{4}$ cells $/$ wells and incubated until 50\%-60\% confluent. Cells were incubated with hyptolide for 48 hours. Culture medium was discarded, and cells were washed with Phosphate Buffer Solution. Coverslips were placed into object-glass and added with $10 \mathrm{ml} 1 \mathrm{x}$ working solution acridine orange (Sigma)-ethidium bromide (Sigma) and then allowed to stand for 5 minutes. Cell immediately flourescent observed under a microscope (Zeiss MC 80). Apoptosis cells that had lost their integrity of membrane appeared orange and showed morphological features of apoptosis. Cells have been classified as apoptosis based on specific morphological criteria, comprising chromatin condensation and fragmentation, and apoptosis body formation. Living cells fluorescence green (with acridine orange) (Amundson et al., 2000).

\section{Statistical analysis}

The data presented the mean \pm standard error of the mean (SE). The statistical analysis was used a one-way analysis of variance followed by the least significant difference test (Excel 2016 software; Microsoft, Redmond, WA). Statistically significant was the $p$-value less than 0.05 .

\section{RESULTS AND DISCUSSION}

\section{Results}

\section{Isolation of hyptolide from Hyptis pectinata (L.) Poit extract}

Hyptolide compounds isolated from the leaves of the plant Hyptis pectinata (L.) Poit have a melting point of $88^{\circ} \mathrm{C}-89^{\circ} \mathrm{C}$. The melting point of hyptolide does not make much difference from the melting point of the compound hyptolide previously reported that are $88.5^{\circ} \mathrm{C}, 88.5^{\circ} \mathrm{C}$, and $87^{\circ} \mathrm{C}-88^{\circ} \mathrm{C}$ (Achmad et al., 1987). As we all know the physical constants such as melting points are still used identifying compounds, but many compounds 
have the same melting point but different in structure. Infrared spectrophotometer analysis has absorption bands at wave number $1,735 \mathrm{~cm}^{-1}$. It is indicating the presence of clusters $\alpha, \beta$ unsaturated $\delta$-lactone as the basic framework of the compound hyptolide. Strong type at wave number $1,735 \mathrm{~cm}^{-1}$ is the carbonyl group in ketones or esters of conjugated. The results of GC-MS analysis are one peak with a retention time of 11.701 minutes and $\mathrm{m} / \mathrm{z}$ at 239 (approximate of molecular weight of hyptolide). Thus, the isolated compounds are hyptolide with the structure are shown in Figure 1.

\section{Cytotoxic activity of hyptolide on MCF-7 and T47D cells}

Cytotoxicity assay was performed to measure the potency of hyptolide-induced cytotoxicity on MCF-7 and T47D cells. The cytotoxic effect of hyptolide was presented the $\mathrm{IC}_{50}$ value and was used to determine the dose for other assays. The results showed that the treatment of hyptolide for 24 hours significantly decreased the viability of the cells with the degree of depletion in a dose-dependent manner on the MCF-7 and T47D. However, the cytotoxic effect was stronger on MCF-7 than on T47D with an $\mathrm{IC}_{50}$ value of $76.76 \mu \mathrm{g} / \mathrm{ml}$ and $181.55 \mu \mathrm{g} / \mathrm{ml}$, respectively (Fig. 2A). This result suggested that the differential expression of protein marked that involved in the cell growth stimulation is more strongly influenced by hyptolide in MCF-7 cells.

\section{Antiproliferation effect of hyptolide on $\mathrm{MCF}-7$ cells}

The cytotoxicity data indicate that $\mathrm{MCF}-7$ is more susceptible to be treated with hyptolide than T47D. Therefore, based on these data, we evaluated the effect of hyptolide on MCF7 cells with variation in time for treatment. Interestingly, the presence of hyptolide on the medium causes highly suppressed cell proliferation with an $\mathrm{IC}_{50}$ value of 63.27 and $33.94 \mu \mathrm{g} / \mathrm{ml}$ for 48 and 72 hours, respectively (Fig. 2B). Therefore, we concluded that hyptolide exhibits strong cytotoxic activity in a dose- and time-dependent manner on MCF-7 cells.

\section{Apoptosis induction by hyptolide on MCF-7 cells}

To verify the mechanism underlying the cytotoxic effect of the hyptolide treatment on MCF-7 cells, we conducted apoptosis assay with acridine orange-ethidium bromide (AO/EB) multiple staining. In this research, we used one-eighth, one-fourth, half, and $\mathrm{IC}_{50}$ value as the concentration of hyptolide. Based on the apoptosis analysis, cells exposed to hyptolide for 48 hours were capable of inducing apoptosis at dose-dependent manner (Fig. 3). Based on the findings, it was evident that the increasing concentration of hyptolide causes a significant reduction in the number of viable cells. In addition, some cells had typical apoptotic characteristics such as plasma membrane blabbing. However, the number of cells

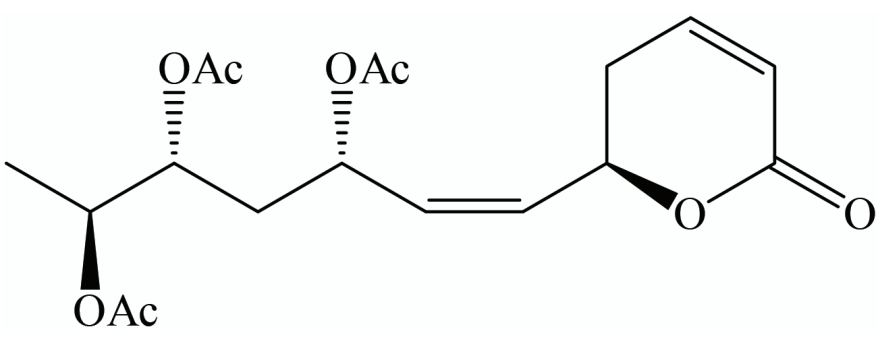

Figure 1. Chemical structures of hyptolide compounds isolated from Hyptis pectinata. stained red increases. This finding suggests that most of the cell deaths occurred primarily through apoptosis.

\section{DISCUSSION}

The purpose of this research was to introduce hyptolide as a natural chemotherapeutic agent to inhibit the proliferation of ER-positive breast cancer cells. The concepts of natural chemotherapy are to improve efficacy and reduce the side effects of a chemical chemotherapeutic agent. Hyptolide is among the natural agents that can be potentially developed to be anticancer. However, studies of the anticancer activity of hyptolide have never been attempted. On the other hand, exploration of the anticancer activity of hyptolide extract was reported in several cancer cells. Hyptis pectinata extract has been shown to prevent cancer growth in several cancer cells such as MDA-MB-231 (Santana et al., 2019) and HCT-8 cells (Barbosa et al., 2012). However, hyptolide, one of the major isolates compound from Hyptis pectinata, has not been observed for cytotoxic activity. Thus, based on this result,
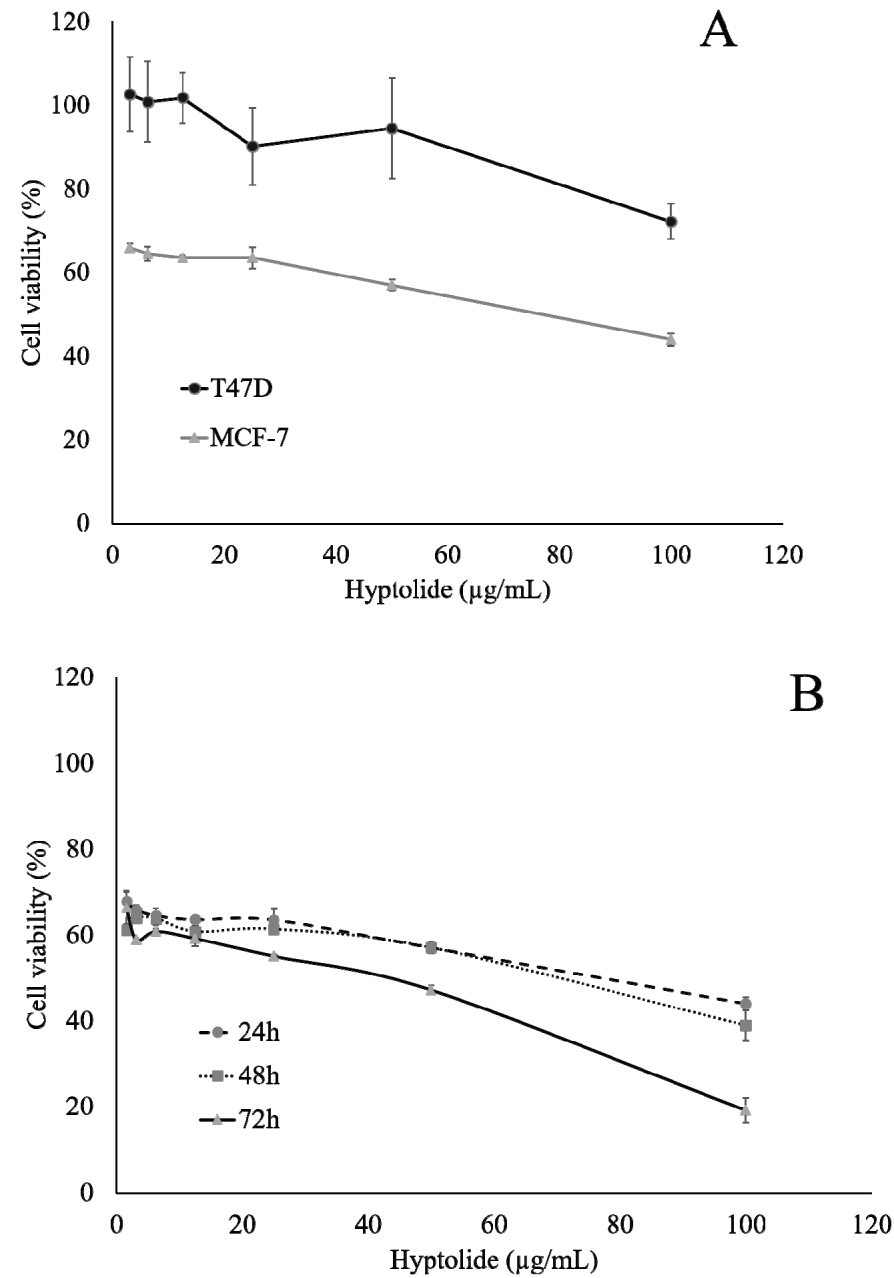

Figure 2. Effect of Hyptolide on the proliferation of MCF-7 and T47D cells. (A) MCF-7 cell $\left(2 \times 10^{4}\right.$ cells $\left./ \mathrm{ml}\right)$ and T47D cell were culture in presence of hyptolide $(3.125-100 \mu \mathrm{g} / \mathrm{ml})$ for 24 hours. (B) MCF-7 cell $\left(\left(2 \times 10^{4}\right.\right.$ cells $\left./ \mathrm{ml}\right)$ in 96-well plates for 24 hours to adapt, then treated with hyptolide concentrations of $1.5625-100 \mu \mathrm{g} / \mathrm{ml}$, then incubated again for 24,48 , and 72 hours. Profiles of cell viability expressed mean $\pm \mathrm{SD}$ of three experiments. $\mathrm{IC}_{50}$ obtained from the linear regression calculation of cell viability versus log concentrations with $p<0.05$. 

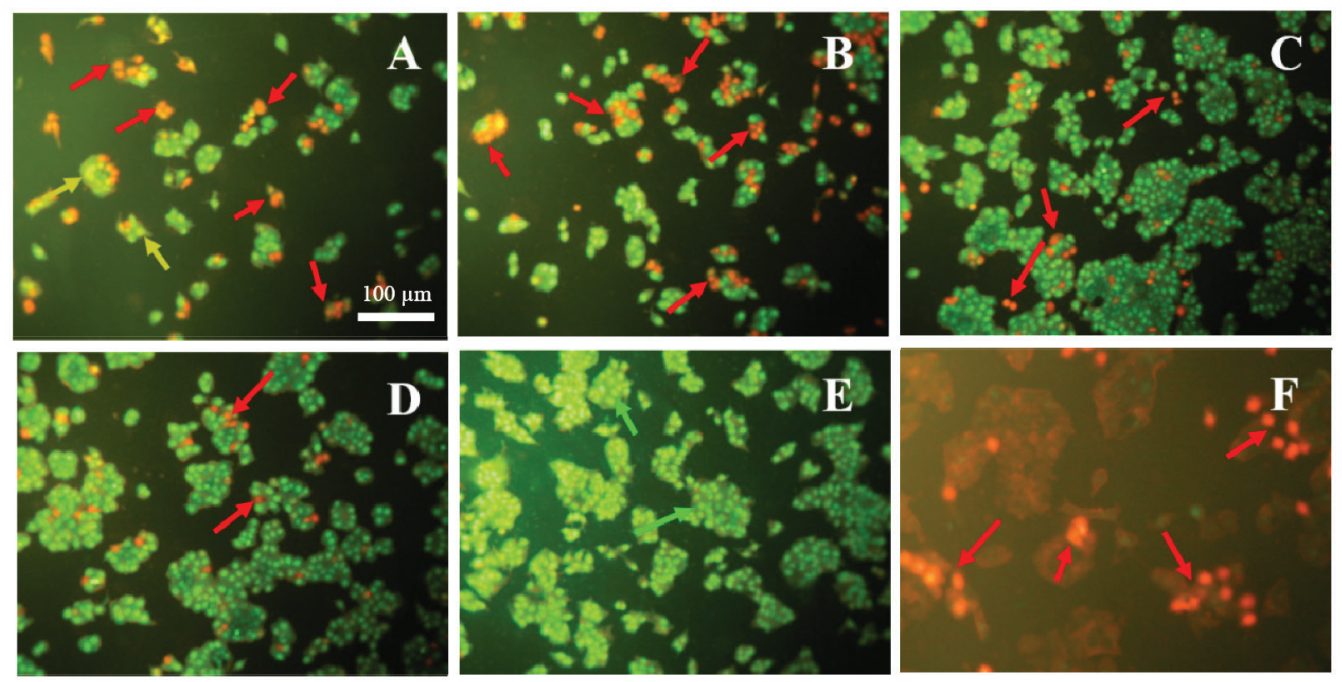

Figure 3. Apoptosis induction of hyptolide on MCF-7 cells. Apoptotic morphology detection by AO/EB fluorescent staining of MCF-7 cells treated with the Hyptolide. $\mathrm{A} \mathrm{IC}_{50} ; \mathrm{b}^{1 / 2} \mathrm{IC}_{50} ; \mathrm{c} \mathrm{c} 1 / 4 \mathrm{IC}_{50} ; \mathrm{d} 1 / 8 \mathrm{IC}_{50}$; e-negative control; f- positive control. Green arrows: live cells, greenish yellow: early apoptotic cells, orange red: late apoptotic cells, red: dead cells (some cells are fragmented and become faded). This figure denotes the results of at least 3 independent experiments (Original magnification 40×).

our group had successfully isolated the hyptolide from Hyptis pectinata (L.) Poit extract, and we evaluated the cytotoxic activity of hyptolide using MCF-7 and T47D ER-positive human breast cancer cells. First, we tested the cytotoxic activity of hyptolide in different concentrations and incubation time on two models of ERpositive breast cancer cells. The single hyptolide treatment showed the cytotoxic effect on MCF-7 cells with an $\mathrm{IC}_{50}$ value of $76.76 \mu \mathrm{g} /$ $\mathrm{ml}$ for 24 hours. We then compared the growth inhibitory actions of hyptolide on another breast cancer cells that is T47D (the ERpositive breast cancer reportedly p53 mutant, while MCF-7 are p 53 wild-type) (Holliday and Speirs, 2011). Interestingly, cytotoxicity of hyptolide is more effective in MCF-7 than in T47D cells $\left(\mathrm{IC}_{50}\right.$ $181.55 \mu \mathrm{g} / \mathrm{ml}$ ) (Fig. 2A). In this study, two types of breast cancer cells showed different responses to treatment with hyptolide. In the same treatment level, $50 \mu \mathrm{g} / \mathrm{ml}$ of hyptolide, cell viability of MCF7 is lower than T47D. The results suggest that MCF-7 is more susceptible than T47D to be treated with hyptolide. It shows that characteristics of MCF-7 are sensitive to the hyptolide. Perhaps this is due to the effect of ER expression (ER), expression of p53 protein wild type, and over-expression of Bcl-2 one of protein marked on apoptosis (Amundson et al., 2000; Berger et al., 2013; Butt et al., 2000; Li et al., 2004; Ma et al., 2013).

Thus, based on these results, we observed cytotoxicity in time variation on MCF-7 cells. Interestingly, the presence of hyptolide on the medium, for 48 and 72 hours, causes highly suppressed cell proliferation and exhibits strong cytotoxic activity in dose- and time-dependent manner on MCF-7 cells (Fig. 2B). One explanation is that there might be a decrease in cell viability caused by the presence of unfunctional ER, induction of p53 protein and caspase 3 (Amaral et al., 2010; Jamalzadeh et al., 2017; Schüler-Toprak et al., 2017). Another report said that $\alpha$-tubulin inhibition is also caused by hyptolide treatment related to its activity on cell proliferation (Asy et al., 2019). However, this phenomenon by which hyptolide suppresses cell proliferation through $\alpha$-tubulin inhibition causing the induction of tumor suppressor gene $\mathrm{p} 53$ should be clarified further.

To obtain a further investigation of the cytotoxicity' mechanism of hyptolide, we observed apoptosis induction of hyptolide by $\mathrm{AO} / \mathrm{EB}$ multiple staining. $\mathrm{AO} / \mathrm{EB}$ multiple staining showed that the differential absorption of the $\mathrm{AO}$ and $\mathrm{EB}$ fluorescent DNA-binding dyes was to determine apoptosis (nonviable) and viable cells. These dyes were used to identify apoptosis cells and to distinguish between cells in the early or late stages of apoptosis stages based on membrane integrity (García-Rodríguez et al., 2013). Early apoptosis cells will have fragmented DNA that gives many green colored nuclei as EB could not penetrate the cells, but chromatin condensation can be visualized as bright green patches in the nuclei. Late apoptosis and necrotic cell DNA would be fragmented and orange-red stained as the EB intercalates into the DNA. Thus, an apoptosis cell will be stained by EB over-whelms AO staining contain a bright orange nucleus. Therefore, using this system one can distinguish between early and late apoptosis cells. Viable cells with intact membranes will have a uniformly stained green nucleus because the $\mathrm{AO}$ intercalates into the DNA.

We explored the effect of hyptolide on physiological changes focusing on the profile of apoptosis (Fig. 3). In this study, the treatment of MCF-7 cells with a low concentration (one-eighth $\mathrm{IC}_{50}$ ) of hyptolide slightly induced apoptosis but did not affect the number of cells grow. In contrast, the high concentration of hyptolide (one $\mathrm{IC}_{50}$ ) highly induced apoptosis and suppresses cells grow compared to the untreated one. Similar results were performed by previous studies in which reported (Tamura et al., 2009; Usui et al., 2004) that pironetin (have a similar structure with hyptolide) could inhibit the growth of HT1080 and 3Y1 cells by apoptosis induction. The apoptosis induction on ER-positive breast cancer cells is due to the role of ER in inhibiting cell growth (Jenie et al., 2019; Rouhimoghadam et al., 2018). According to this finding, cell viability response that under hyptolide treatment 
showed a dose-dependent phenomenon and most of the cell deaths occurred predominantly through apoptosis.

In the present study, we found the mechanism of cell death by hyptolide through apoptosis induction. However, the molecular mechanisms involved in hyptolide-induced inhibition in the progression of cancer cells need to be further explored. Nevertheless, we suggest the use of hyptolide as a novel approach to suppress tumorigenesis by using induced apoptosis mechanism.

\section{CONCLUSION}

In the present study, authors have investigated the cytotoxic effect of hyptolide on two types of estrogen-positive human breast cancer cells. The results demonstrated that the cytotoxic effect of hyptolide on MCF-7 is stronger than T47D cells using the MTT assay. Authors also found hyptolide highly suppressed cell proliferation in the dose- and time-dependent manner on MCF-7 cell. This effect was mediated through apoptosis induction by analysis of $\mathrm{AO} / \mathrm{EB}$ multiple staining assay. More importantly, our findings suggest that hyptolide has the potential to be developed as a natural chemotherapeutic agent with better effects and possibly fewer side effects.

\section{ACKNOWLEDGMENT}

We express our gratitude to Fundamental Research Grant Ministry of Research Technology and Higher Education, The Republic of Indonesia who funded this research.

\section{CONFLICT OF INTEREST}

The authors declare that there is no conflict of interest relevant to the contents of this article.

\section{REFERENCES}

Achmad S, Hoyer T, Kjaer A, Makmur L, Norrestam R Molecular and crystal structure of hyptolide, a naturally occuring $\alpha, \beta$ unsaturated $\delta$-lactone. Acta Chemica Scandinavca B 1987; 41:599-609.

Amaral JD, Xavier JM, Steer CJ, Rodrigues CMP. Targeting the p53 pathway of apoptosis. Curr Pharm Des 2010; 16:2493-503.

Amundson SA, Myers TG, Scudiero D, Kitada S, Reed JC, Fornace J. An informatics approach identifying markers of chemosensitivity in human cancer cell lines. Cancer Res 2000; 60:6101-10.

Ariazi EA, Jordan VC. Estrogen-related receptors as emerging targets in cancer and metabolic disorders. Curr Top Med Chem 2006; $6: 203-15$

Arrigoni-Blank MF, Antoniolli AR, Caetano LC, Campos DA. Antinociceptive activity of the volatile oils of hyptis pectinata L. Poit (Lamiaceae) genotypes. Phytomedicine 2008; 15:334-9.

Asy M, Diponegoro U, Suzery M, Diponegoro U. In silico study: the anticancer potency og hyptolide and analogue compounds through mechanism of $\alpha$-tubulin inhibition. Int J Pharm Bio 2019; 243-8.

Barbosa CV, Aquino PGV, Ribeiro-Junior KAL, Moura FBP, Alexandre-Moreira MS, Sant'Ana AEG, Ferreira JRO, Moraes MO, Pessoa C, Aguiar JS, Silva TG. Cytotoxic and antitumor activities of hyptis pectinata (Sambacaitá) extract. Pharmacologyonline 2012; 3:70-4.

Berger C, Qian Y, Chen X. The p53-estrogen receptor loop in cancer. Curr Mol Med 2013; 13:1229-40.

Butt AJ, Firth SM, King MA, Baxter RC. Insulin-like growth factor-binding protein-3 modulates expression of Bax and $\mathrm{Bcl}-2$ and potentiates p53-independent radiation-induced apoptosis in human breast cancer cells. J Biol Chem 2000; 275:39174-81.

Falcao RA, Nascimento PLA, de Souza SA, Silva TMG, de Queiroz AC, Matta CBB, Moreira MS, Camara CA, Silva T. Antileishmanial
Phenylpropanoids from the Leaves of Hyptis pectinata (L.) Poit. J EvidenceBased Complement Altern Med 2013.

Franzotti EM, Bomfim KBR, Moreno MPN, Marchioro M, Antoniolli AR. Antinociceptive and antiedematogenic effects of the aqueous extract of Hyptis pectinata leaves in experimental animals. J Etnopharmacol $2001 ; 76: 81-6$.

García-Rodríguez MDC, Carvente-Juárez MM, AltamiranoLozano MA. Antigenotoxic and apoptotic activity of green tea polyphenol extracts on hexavalent chromium-induced DNA damage in peripheral blood of CD-1 mice: analysis with differential acridine orange/ethidium bromide staining. Oxid Med Cell Longev 2013.

Holliday DL, Speirs V. Choosing the right cell line for breast cancer research. Breast Cancer Res 2011; 13:215-22.

Hollingsworth AB, Lerner MR, Lightfoot SA, Wilkerson KB, Hanas JS, McCay PB, Brackett DJ. Prevention of DMBA-induced rat mammary carcinomas comparing leuprolide, oophorectomy, and tamoxifen. Breast Cancer Res Treat 1998; 47:63-70.

Jamalzadeh L, Ghafoori H, Aghamaali M, Sariri R. Induction of apoptosis in human breast cancer MCF-7 cells by a semi- synthetic derivative of artemisinin: a caspase-related mechanism. Iran J Biotechnol 2017; $15: 157-65$

Jenie RI, Amalina ND, Ilmawati GPN, Utomo RY, Ikawati M, Khumaira A, Kato JY, Meiyanto E. Cell cycle modulation of CHO-K1 cells under Genistein treatment correlates with cells senescence, apoptosis and ROS level but in a dose-dependent manner. Adv Pharm Bull 2019; 9:453.

Kayl AE, Meyers CA. Side-effects of chemotherapy and quality of life in ovarian and breast cancer patients. Curr Opin Obstet Gynecol $2006 ; 18: 24-8$

Lewis-Wambi JS, Jordan VC. Estrogen regulation of apoptosis: how can one hormone stimulate and inhibit? Breast Cancer Res 2009; 11:206.

Li DQ, Pan LH, Shao ZM. Reversal effects of mifepristone on multidrug resistance(MDR) in drug-resistant breast cancer cell line MCF7/ ADR in vitro and in vivo. Chinese J Cancer Res 2004; 16:93-8.

Lisboa ACCD, Mello ICM, Nunes RS, Santos MA, Antoniolli AR, Marçal RM, Cavalcanti SC. Antinociceptive effect of Hyptis pectinata leaves extracts. Fitoterapia 2006; 77:439-42.

Ma L, Liu Y, Geng C, Qi X, Jiang J. Estrogen receptor $\beta$ inhibits estradiol-induced proliferation and migration of MCF-7 cells through regulation of mitofusin 2 Corrigendum. Int J oncol 2013; 42:1993-2000.

Mardela AP, Maneewat K, Sangchan H. Breast cancer awareness among Indonesian women at moderate-to-high risk. Nurs Heal Sci 2017; 19:301-6.

Miranda RP, Hernadez L, Villavicencio MJ, Novelo M, Ibarra P. Structure and stereochemistry of pectinolides A-C novel antimicrobial and cytotoxic 5,6-dihydro- $\alpha$-pyrones from hyptis pectinata. J Nat Prod 1993; 56:583-93.

Mosmann T. Rapid colorimetric assay for cellular growth and survival: Application to proliferation and cytotoxicity assays. J Immunol Methods 1983; 65:55-63.

Paruthiyil S, Parmar H, Kerekatte V, Cuncha GR, Firestone GL, Leitman DC. Estrogen receptor $\beta$ inhibits human breast cancer cell proliferation and tumor formation by causing a G2 cell cycle arrest. Cancer Res 2004; 64:423-8.

Raymundo LJRP, Guilhon CC, Alviano DS, Eline M, Antoniolli AR, Cavalcanti SCH, Alves PB, Alviano CS, Fernandes PD. Characterisation of the anti-inflammatory and antinociceptive activities of the Hyptis pectinata (L.) poit essential oil. J Ethnopharmacol, 2011; 134:725-32.

Rouhimoghadam M, Safarian S, Carroll JS, Sheibani N, Bidkhori G. Tamoxifen-induced apoptosis of MCF-7 cells via GPR30/PI3K/MAPKs interactions: Verification by ODE modeling and RNA sequencing. Front Physiol 2018; 9:907.

Roy S, Vadlamudi RK. Role of estrogen receptor signaling in breast cancer metastasis. Int J Breast Cancer 2012. 
Santana FR, Luna-Dulcey L, Antunes VU, Claudio F, Cominetti MR, Duarte MC, da Silva JA. Evaluation of the cytotoxicity on breast cancer cell of extracts and compounds isolated from Hyptis pectinata (L.) poit. Nat Prod Res 2019; 1-8.

Sasco AJ. Breast cancer and the environment. Horm Res 2003; $60: 50$

Schüler-Toprak S, Moehle C, Skrzypczak M, Ortmann O, Treeck O. Effect of estrogen receptor $\beta$ agonists on proliferation and gene expression of ovarian cancer cells. BMC cancer 2017; 17:319.

Sinaga ES, Ahmad RA, Shivalli S, Hutajulu SH. Age at diagnosis predicted survival outcome of female patients with breast cancer at a tertiary hospital in Yogyakarta, Indonesia. Pan Afr Med J 2018; 31:1-9.

Suzery M, Cahyono B. Jurnal Sains dan matematika evaluation of Cytotoxicity effect of hyptis pectinata poit (Lamiaceae ) extracts using BSLT and MTT methods. J Sains dan Matematika 2014; 22:84-8.

Suzery M, Kusniawati E, Hudiyanti D, Cahyono B. Isolasi senyawa $\mathrm{C}_{18} \mathrm{H}_{26} \mathrm{O}_{9}$ dari hiptolida hasil isolasi daun Hyptis pectinata. Reaktor $2012 ; 14: 68-72$.

Tacar O, Sriamornsak P, Dass CR. Doxorubicin : an update on anticancer molecular action. J Pharm Pharmacol 2013; 65:157-70.

Takimoto $\mathrm{BCH}$, Calvo E. Principles of oncologic pharmacotherapy. Physician Practice 2005; 1-16.

Tamura Y, Simizu S, Muroi M, Takagi S, Kawatani M, Watanabe $\mathrm{N}$, Osada H. Polo-like kinase 1 phosphorylates and regulates Bcl-x L during pironetin-induced apoptosis. Oncogene 2009; 90:107-16.
Tian JM, Ran B, Zhang CL, Yan DM, Li XH. Estrogen and progesterone promote breast cancer cell proliferation by inducing cyclin G1 expression. Braz J Med Biol Res 2018; 51:5612.

USDA N. The PLANTS database. National Plant Data Team, Greensboro, NC. 2016.

Usui T, Watanabe H, Nakayama H, Tada Y, Kanoh N, Kondoh M, Asao T, Takio K, Watanabe H, Nishikawa K, Kitahara T. The anticancer natural product pironetin selectively targets Lys352 of $\alpha$-tubulin. Chem Biol 2004; 11:799-806.

WHO. Latest global cancer data: Cancer burden rises to 18.1 million new cases and 9.6 million cancer deaths in 2018. Int Agency Res Cancer 2018:13-5.

How to cite this article:

Suzery M, Cahyono B, Amalina ND. Antiproliferative and apoptosis effect of hyptolide from Hyptis pectinata poit on human breast cancer cells. J Appl Pharm Sci, 2020; 10(02):001-006. 